\title{
Assisted dying: it's time to poll UK doctors
}

\author{
Fiona Godlee editor in chief
}

The BMJ

Doctors' organisations provide crucial leadership, cohesion, a community, resources, and support for their members. They also speak for the profession; their positions on ethical issues are therefore of great importance to national debate. The BMA and the key medical royal colleges remain opposed to assisted dying. So too do the American Medical Association, the American College of Physicians, and the American Academy of Family Physicians, despite assisted dying being legally available to 58 million Americans in six states and the District of Columbia.

These organisations' positions have long been out of step with the general public: polls in the UK and the US have suggested more than $80 \%$ support for assisted dying. More worryingly, their positions seem also now to be out of step with doctors. As Bob Roehr reports (doi:10.1136/bmj.k503), surveys of US doctors show a growing majority in favour of assisted dying. Small surveys in the UK have found the same (doi:10.1136/bmj. k301).

Our Head to Head debate samples views of two former presidents of the Royal College of Surgeons (doi:10.1136/bmj. $\mathrm{k} 562$ ). Bernard Ribiero says that assisted dying would harm relations between doctors and patients and should be a matter for the courts, not the consulting room. Terence English believes that, provided adequate safeguards are in place, an individual's right to self determination must be paramount.
In parts of the world where it is legal, assisted dying works well, says Roehr. Nor is it incompatible with excellent palliative care, says clinical ethicist Bobbie Farsides (doi:10.1136/bmj.k544).

Jacky Davis argues, as The BMJ has done (doi:10.1136/bmj. e4075), that legalisation should be a decision for society and parliament, not doctors (doi:10.1136/bmj.k301). A consultant radiologist, Davis is chair of Healthcare Professionals for Assisted Dying and is also a member of the BMA council. Opposition means that organisations exclude themselves from constructive debate, she says, and she calls on the BMA to poll its members, which so far it has declined to do.

Some royal colleges have polled their members, but social and medical attitudes are changing, so they would do well to repeat this. Better still, we need a large national and independent opinion poll, perhaps commissioned jointly by the BMA, the royal colleges, and the GMC. In the meantime, a neutral position from medical organisations would do most to promote an open and informed public debate.

\section{Follow Fiona on Twitter: @fgodlee}

Read all of The BMSs articles on assisted dying at bmj.com/content/ assisted-dying

Published by the BMJ Publishing Group Limited. For permission to use (where not already granted under a licence) please go to http://group.bmj.com/group/rights-licensing/ permissions 